\title{
IMPROVING THE ABILITY IN WRITING PARAGRAPH AT THE SECOND GRADE STUDENTS OF SMK NEGERI 5 PINRANG THROUGH PARAPHRASING TECHNIQUE
}

\author{
Siti Lestari ${ }^{1}$, Nurhamdah ${ }^{2}$ \\ English Program, Tarbiyah Faculty, State Islamic Institute of Parepare ${ }^{12}$ \\ tary8834@gmail.com ${ }^{1}$
}

\begin{abstract}
This study is to see improving writing abilityat the secondgrade students of SMK Negeri 5 Pinrang through Paraphrasing Technique. It aimed to know whether Paraphrasing Technique can improve the students' Writing Ability in Writing Paragraph. The subject of this research is XI TGB class which is consisted of 17 students. The sample was taken by using random sampling. The design in this research was pre-experimental with pre-test and post-test design. The students did the pre-test, got the treatment and did the post-test. The result in this research was indicated that there was improvement of the students' Writing Ability.It was indicated by the students' mean scoreof post-test (81.48) was greater than pre-test (50.58). Even, for the level significant (p) $5 \%$ and $\mathrm{df}=17$, and the value of table is 1.746 , while the value of t-test is 14,26 . it means that, the t-test value is greater than t-table $(14,26 \geq 1.746)$. Thus, it can be concluded that the students' Writing ability in writing paragraph is significant better after getting the treatment. So, the null hypothesis $\left(\mathrm{H}_{0}\right)$ is rejected and the alternative hypothesis $\left(\mathrm{H}_{\mathrm{a}}\right)$ is fail rejected.
\end{abstract}

Keywords: Writing Ability, Paraphrasing Technique.

\section{Introduction}

English is one of the international languages that is used by many people in the world and in many areas of everyday life. Besides, English is a mayor of communication among people use it as a means of international communication. English has been used as the second language. It has great influence all over the world. Therefore, using English is the easiest way to communicate with people from other countries about many aspects in human life such as technology, 
economy, social, and politic. It is considered as an instructional language and use all over the world.

Learning English as a foreign language is an integrated process that the learner should study the four basic abilities: listening, speaking, reading, and writing. people use it to understand the world through listening and reading and to communicate their feeling, need, and desires through speaking and writing. By having more knowledge about language ability people have much better chance of understanding and being understood and getting what people want and need from around them. These abilities cannot be separated because have relation to each other.

Writing is one of four basic abilities and, in this research, the researcher will focuses on writing ability especially in writing paragraph. Cral said that in his book Writing is basically a process of communicating something (content) on paper to an audience (Cral Thomas, 1993). Writing is very important ability to learn because students can describe their idea, feeling, and experience. But not all students can write well when they are writing, they face some difficulties. They do not master vocabulary, punctuation, grammar, and how to use appropriate words. In addition, technique or media of the teacher does not make students interested to learned and made them got bored. The teacher should create comfortable learning situation to overcome the problems of the students, or over help and motivate the students in order to express their ideas into writing.

Paraphrasing is one of the ways to overcome writing problems. Paraphrasing is rewriting using different words. Changing the wording of text that it is significantly different from the original source, without changing the meaning (Stephen Bailey, 2011). For example, if the students have read a story and they wanted to tell their friends about the story happened, they have to recounted the storyline, the main characters, the events, and important points using their own words. Paraphrasing will help the students to understand writer's idea and to clarify the meaning of a sentence of passage. 


\section{Method}

This research used pre-experimental design with pre-test and post-test design. The students did the pretest, got the treatment and did the post-test. It aimed to know whether the Paraphrasing technique can improve the students' writing ability in writing paragraph. The following is the formula:

$$
\begin{array}{lll}
\mathrm{O}_{1} & \mathrm{X} & \mathrm{O}_{2}
\end{array}
$$

Where: O1: Pretest X: TreatmentO2: Posttest

This research took a place at SMK Negeri 5 Pinrang which is located in Bettoeng. The subject of this research is the second-grade students of SMKN 5 Pinrang, second semester of the 2017/2018 academic year. The researcher took class XI as the subject of the research which consist of 18 students.

The population of the research was the second-year students of SMKN 5 Pinrang academic year 2017/2018. XI TGB, XI AP, XI Akuntansi the total of population were 79 students.

The sample was taken by using random sampling, each class has the same chance to be randomly, selected into a sample, done by shuffling the class and later the outgoing class that is used as a sample. And the selected class is class XI TGB which is consisted of 18 students as the sample in this research, because from the three classes have the same ability in English. so that, by random all the classes in the second grade and choosing one class from the three classes as the sample can be represent the other classes.

In collecting the data, the researcher used pre-test that intended to see students' ability in writing paragraph before applying the treatment, while the post-test was intended to know the improvement of students' writing text 
especially writing paragraph by paraphrasing the text. The researcher came to the classroom and gave greeting and motivation to students. The researcher gave explanation to students about this research. The researcher gave the students explanation about writing and how to paraphrasing the text. And there areprocedures of collecting data are divided in three stages, namely:

Table 1 the classification of students' score

\begin{tabular}{|c|c|c|c|}
\hline No. & Aspects & Criteria & Scores \\
\hline \multirow[t]{4}{*}{1.} & Content & - Relevant to topic. & 4 \\
\hline & & - Mostly relevant to topic but lacks detail. & 3 \\
\hline & & - Inadequate development of topic. & 2 \\
\hline & & - Not relevant to topic. & 1 \\
\hline \multirow[t]{4}{*}{2.} & Organization & $\begin{array}{l}\text { - Ideas clearly stated and supported, well } \\
\text { organized (generic structure), cohesive. }\end{array}$ & 4 \\
\hline & & $\begin{array}{l}\text { - Loosely organized but main ideas stand out, } \\
\text { not well organized (generic structure). }\end{array}$ & 3 \\
\hline & & $\begin{array}{l}\text { - Ideas confused or even no main ideas, bad } \\
\text { organization (generic structure). }\end{array}$ & 2 \\
\hline & & $\begin{array}{l}\text { - Does not communicate, no organization } \\
\text { (generic structure). }\end{array}$ & 1 \\
\hline \multirow[t]{4}{*}{3.} & Vocabulary & - Effective word / idiom choice and usage. & 4 \\
\hline & & $\begin{array}{l}\text { - Occasional errors of word / idiom form, } \\
\text { choice and usage. }\end{array}$ & 3 \\
\hline & & $\begin{array}{l}\text { - Frequent errors of word / idiom form, choice } \\
\text { and usage. }\end{array}$ & 2 \\
\hline & & $\begin{array}{l}\text { - Little knowledge of English vocabulary, } \\
\text { idioms and word form. }\end{array}$ & 1 \\
\hline \multirow[t]{4}{*}{4.} & $\begin{array}{l}\text { Language } \\
\text { Use }\end{array}$ & $\begin{array}{l}\text { - Few errors of agreement, tense, number, word } \\
\text { order, articles, pronouns or prepositions. }\end{array}$ & 4 \\
\hline & & - Several errors of agreement, tense, number, & 3 \\
\hline & & $\begin{array}{l}\text { word order, articles, pronouns or prepositions. } \\
\text { - Frequent errors of agreement, tense, number, }\end{array}$ & 2 \\
\hline & & $\begin{array}{l}\text { word order, articles, pronouns or preposition. } \\
\text { - Dominated by errors. }\end{array}$ & 1 \\
\hline \multirow[t]{4}{*}{5.} & Mechanics & $\begin{array}{l}\text { - Few errors of spelling, punctuation, } \\
\text { capitalization and paragraphing. }\end{array}$ & 4 \\
\hline & & $\begin{array}{l}\text { - Occasional errors of spelling, punctuation, } \\
\text { capitalization, and paragraphing. }\end{array}$ & 3 \\
\hline & & $\begin{array}{l}\text { - Frequent errors of spelling, punctuation, } \\
\text { capitalization and paragraphing. }\end{array}$ & 2 \\
\hline & & - Dominated by errors. & 1 \\
\hline
\end{tabular}


7nspiring: English Education Journal

Volume 2 No I Maret 2019

Adapted from Jacob et al. 's (1981)

Table 2 classification students' score

\begin{tabular}{ccc}
\hline No. & Classification & Score \\
\hline 1. & Very Good & $80-100$ \\
2. & Good & $66-79$ \\
3. & Fair & $56-65$ \\
4. & Poor & $40-55$ \\
5. & Very poor & $\leq 39$ \\
\hline
\end{tabular}

\section{Findings}

The pre-test had done before giving the treatment. The students were given a pre-test, the researcher fond out the result of students' writing skills in pre-test based on the aspects of writing before giving paraphrasing technique which were content, organization, vocabulary, language use, as well as mechanics, which were analyzed and resulted in the information as shown in the following table:

Mean score of the pre-test:

$\mathrm{X}=\frac{\sum x}{N}=\frac{860}{17}=50.58$

Thus, the mean score $\left(\mathrm{X}_{1}\right)$ of pre-test is 50.58

The standard deviation of the pre-test

$$
\mathrm{SD}=\sqrt{\frac{\sum \mathrm{X}^{2}-\frac{\left(\sum \mathrm{X}\right)^{2}}{\mathrm{~N}}}{\mathrm{~N}-1}}=\sqrt{56.195}=\mathbf{7 . 4 9}
$$

Thus, the standard deviation of the pre-test is 7.49

$$
\mathrm{X}=\frac{\sum x}{N}=\frac{1.385}{17}=81.48
$$

Thus, the mean score $\left(\mathrm{X}_{2}\right)$ of post-test is 81.48

The standard deviation of the post-test 


$$
\mathrm{SD}=\sqrt{\frac{\sum \mathrm{X}^{2}-\frac{\left(\sum \mathrm{X}\right)^{2}}{\mathrm{~N}}}{\mathrm{~N}-1}}=\sqrt{108.64}=\mathbf{1 0}, \mathbf{4 2}
$$

Thus, the SD of the post-test is 10,42

Table 3 The mean score and standard deviation of the pre-test and post-test

\begin{tabular}{ccc}
\hline Test & Mean Score & Standard Deviation (SD) \\
\hline Pre-test & 50.58 & 7.49 \\
Post-test & 81.48 & 10.42 \\
\hline
\end{tabular}

The following table shows the percentage of the frequency in pre-test and post-test.

Table 4 the rate percentage of the frequency of the pre-test and post-test

\begin{tabular}{llccccc}
\hline & & & \multicolumn{2}{c}{ Frequency } & \multicolumn{2}{c}{ Percentage } \\
\cline { 3 - 6 } No. & Classification & Score & Pre-test & $\begin{array}{c}\text { Post- } \\
\text { test }\end{array}$ & Pre-test & Post-test \\
\hline 1. & Very Good & $80-100$ & 0 & 12 & 0 & 70,5 \\
2. & Good & $66-79$ & 0 & 3 & 0 & 17,6 \\
3. & Fair & $56-65$ & 2 & 2 & 11,7 & 11,7 \\
4. & Poor & $40-55$ & 14 & 0 & 82,3 & 0 \\
5. & Very Poor & $\leq 39$ & 1 & 0 & 5,8 & 0 \\
& Total & & 17 & 17 & $100 \%$ & $100 \%$ \\
\hline
\end{tabular}

Paraphrasing technique is able to improve the Students' Writing Ability in Writing Paragraph at the Second Grade Students of SMK Negeri 5 Pinrang.

In the other to see the students' score, the following is t-test was statistically applied:

Find ou $\mathrm{D}=\frac{\sum D}{\mathrm{~N}} \mathrm{t}=\frac{525}{17}=30.8$

The calculation the t-test value $: t=\frac{\mathrm{D}}{\sqrt{\frac{\sum^{2}-\frac{\left(\sum D\right)^{2}}{N}}{N(N-1)}}}=\frac{30.8}{2.16}=\mathbf{1 4 . 2 6}$

Thus, the t-test value is 14.26 
Table 5 The test of significance

\begin{tabular}{ccc}
\hline Variable & T-test & T-table value \\
\hline Pre-test - post-test & 14.26 & 1.74 \\
\hline
\end{tabular}

The data above showed that the value of t-test was greater than t-table value. It indicated that there was a significance difference between the result students' pre-test and post-test.

\section{Discussion}

The researcher used paraphrasing technique to make the students easy to write their ideas in writing paragraph. the researcher checked the students error of writing by focusing on the aspect of writing which are content, organization, vocabulary, language use, as well as the mechanic. The researcher checked the students' error by guiding of them Based on the aspects of writing. These aspects also were a guideline of researcher in scoring the students' writing test. The students' writing ability increased after giving treatment. Because from the students' score in the pre-test before that was 50.58 and categorized as poor classification and after giving treatment that was 81.48 and categorized as very good classification.

By looking at the test finding, from the data provided in classification table based on the aspects of writing, clearly to see that two (11.7\%) students got fair score, fourteen (82.3\%) students got poor score and one (5.8\%) students got very poor score while in the post-test, twelve (7.5\%) students got very good score, three (17.6\%) students got good score and two (11.7\%) students got fair score. From the result, the researcher concluded that the students' writing ability improved from very poor to very good classification.

In addition, to know what was the hypothesis receipt between null hypothesis ( $\mathrm{H} 0)$ was and alternative hypothesis $\left(\mathrm{H}_{\mathrm{a}}\right)$, the researcher used t-test to calculating result showed that on the t-test value 14,26 was greater than t-table value 1.746 table $(14.26 \geq 1.746)$ with degree of freedom (df) 16 . It means alternative hypothesis $\left(\mathrm{H}_{\mathrm{a}}\right)$ was concluded that the paraphrasing technique was able to improve the students writing ability in writing paragraph at the second- 
gradestudents of SMK Negeri 5 Pinrang. This hypothesis was accepted while the null hypothesis $\left(\mathrm{H}_{0}\right)$ was rejected.

Based on the findings above, the researcher concluded that there was an improving of using paraphrasing technique in students' writing ability in writing paragraph of SMK Negeri 5 Pinrang.

\section{Conclusions}

Based on the result of data analysis and the discussion of the result in previous chapter, the finding of the result showed the positive impact in the students' writing ability and class situation. This study is categorized preexperiment research design, the objective in this study is to find out whether paraphrasing technique was able or not to improve students' writing ability in writing paragraph. Therefore, the researcher concluded that there is a significant difference of the students' writing ability before and after treatment. The following are the description of the conclusion based on the problem statement of this research: T-test result in which the value of t-test was 14.26. It was greater than t-table was 1.746 at the level significance 0.05 and degree of freedom (df) was 16. And the mean score of pre-test (50.58), standard deviation (7.49), and the mean score of post-test (81.48) and the standard deviation (10.42)

Based on the description of the result above, it can be proved by looking at the mean score of the students' writing test in pre-test and post-test. The mean score of pre-test (50.58) is lower than the mean score of post-test (81.48). Then, the t-test (14.26) was greater than t-table (1.746). it means that the null hypothesis $\left(\mathrm{H}_{0}\right)$ was rejected and the alternative hypothesis $\left(\mathrm{H}_{\mathrm{a}}\right)$ was fail rejected.

\section{References}

Alice, Maclin. 1992. Handbook of English as a Second Language.

Ann, Hongue. 1996. First Step in Academic Writing. New York: AddisionWesley Publishing Company.

Bailey, Stephen. 2011. Academic Writing A Handbook for International Students. London and New York: Routledge. 
Byrne, Donn. 1988. Teaching Writing Abilities. Longman: Longman Group UK Limited.

Brown, H. Douglas . 2003. Languge Assesment Principles and Classroom Practices. San Fransisco State University

Banchard, Karen and Christine Root. 1995. Ready to Write a First Composition Text. New York: AddisionWasley Longman.

Brimley Norris, Carolyn. 2016. Academic Writing in English. University of Helsinki: Language Services.

Cañada College Academic Integrity Committee,.2004/8/30. Retrieved from: http://www.canada.edu.insideacad_integrityparaphrasingstrategies.pdf on January 2012

Cral, Thomas. 1993. Creatives Classroom activities. Washington, D. C: United States Information agency.

Dirjen.Pendidikan Dasar dan Menengah. 2005. Peraturan Direktorat Jendral Pendidikan Dasar dan Menengah tentang Penilaian Perkembangan Anak Didik, Jakarta : Depdikbud.

Fromkin, Victoria. 1983. An introduction to language. CBS College Publishing.

Hornby, A, S. 1995. Oxford Learner's Dictionary. New York: oxford University Press

Harmer. 2004. How To Teach Writing. London: Longman.

Harmer, Jeremy. 2001. How to Teach Writing. England: Pearson Education Limited.

Heaton, J. B. 1975. Writing English Language Tests. New York: Longman Inc.

Heaton, J. B. 1988. Writing Language Test. New York: Longman Group.

Maulidya, Diah Hans. 2010. “ The Effectiveness of Paraphrasing Strategy in Increasing University Students' Reading Comprehension and Writing Achievement," Published Thesis; Master Program of English Education: Palembang.

Master, Peter. 1992. English Grammar and Technical Writing.

Oshima, Alice and Ann Hogue. 2007. Introduction to Academic Writing. New York: Pearson Lonman.

O’ Donnel and Teresa D. 1993. Independent writing. Bostom: Heinle \& Heinle Publishers 
Odyssey. Retrieved from :http://www.time4learning.com/teachingwriting.shtml\#process on January 2012.

Owl. 2004. Definition Paraphrasing. Retrieved from http://owl.English.perdue.edu/owl/resource/619/01 on January 2012

Paha, Steve. 1995. Writing process. Retrieved from: http://www.ttms.org on February 2012

Rahayu Sri. 2014. "The Ability Of The Second Year Students Of SMPN 3 Baranti In Identifying And Analyzing Kinds Of Paragraph In Writing”. Unpublished Scrips; English Department: Parepare

Ramsley, H Fowler. 2001. The Little Hand Book. Boston: Little, Brown and Company.

Ricard, Noudquist. 2007. GrammarandComposition. Retrieved from: http://www.grammar.about.com on February 2012

Sonia Ayu Habibah Fisher. 2016. "Students' Reading Techniques Difficulties In Recount Text,". Journal of English and Education 4, no.2

Sukidin. 2002. Manajemen Penelitian Tindakan Kelas. Surabaya. Insan Cendekia http://www.lc.unsw.edu.auonlinepdfparaquo.pdf Retrieved on January 2012

Sugiyono, 2015. Metode Penelitian Pendidikan. Bandung: Alfabeta

Saepudin. 2014. An Introduction to English Learning and Teaching Methodology. Yogyakarta: Trust Media.

Syahrir, Parha. 2015. "Project Based Learning to Improve Students' Writing Ability at the Tenth Grade Students' of SMAN 3 Pinrang". Unpublished Scrips; English Department: Parepare.

Wardiman Artono, Masduki B. Jahur, and M. Sukirman Djusuma. 2008. English In Focus For Grade VIII Junior High School. Jakarta. Pusat Perbukuan Department Pendidikan Nasional

Widiati Utami, Zuliati Rohmah, and Furaidah. 2016. Bahasa Inggris SMA/MA/SMK/MAK Kelas X - Study dan Pengajara. Jakarta. Kementrian Pendidikan dan Kebudayaan

Wilcox Peterson, Patricia. 2003. "Developing Writing" Washington: United States Department of State.

Wy. Dirgeyasa, I. 2016. "English and Literature Department, Faculty of Languages and Arts, UniversitasNegeri Medan, Indonesia: Genre-Based Approach: What and How to Teach and to Learn Writing." Canadian Center of Science and Education 9 no. 9. 
7nspiring: English Education Journal

Volume 2 № I Maret 2019

Yee Lee, Mun. 2012. "Effect of Teaching Paraphrasing Abilities to Students Learning Summary Writing in ESL," the English Language Education Publishing 17, no. 2. 